\title{
Pengaruh Pendidikan Pesantrenisasi Terhadap Motivasi Hidup Islami Mahasiswa
}

\author{
Syahdara Anisa Makruf *, Zalik Nuryana ** \\ * Fakultas Bisnis dan Ekonomika, Universitas Islam Indonesia \\ ** Pendidikan Agama Islam, Universitas Ahmad Dahlan
}

\begin{tabular}{|c|c|}
\hline INFO ARTIKEL & ABSTRAK \\
\hline Riwayat Artikel: & Abstract: Pesantren is a program initiated by the Indonesian Islamic \\
\hline Diterima: 13-02-2021 & University to increase learning Islamic Religious Education in tertiary \\
\hline Disetujui: $21-02-2021$ & institutions. This research uses qualitative and quantitative approaches. A \\
\hline & $\begin{array}{l}\text { qualitative approach is carried out by examining library sources, observing } \\
\text { pesantrenisation activities and interviews with students, musyrif / musyrifah }\end{array}$ \\
\hline \multirow{21}{*}{$\begin{array}{l}\text { Kata kunci: } \\
\text { Revitalization } \\
\text { Pesantrenisasi } \\
\text { Ulil Albab }\end{array}$} & $\begin{array}{l}\text { and lecturers of Islamic Rellgious Eaucation. Wnile the quantitative approacn is } \\
\text { carried out by distributing questionnaires with random sampling techniques, }\end{array}$ \\
\hline & namely 60 respondents, to be processed with a simple linear regression \\
\hline & approach through the SPSS 25 tool. The results showed an effect of the \\
\hline & $\begin{array}{l}\text { pesantren program on students Islamic life motivation, namely } 0.461 \text {. } \\
\text { Meanwhile, the correlation value is } 0.679 \text {. The significance value is } 0.000 \text {, which }\end{array}$ \\
\hline & is $<0.05$, so it shows that there is an effect of pesantren (X) on students' Islamic \\
\hline & life motivation $(\mathrm{Y})$. Therefore, the revitalization of the pesantren program can \\
\hline & be used as a reference to increase the cultivation of Islamic values in realizing \\
\hline & UII's mission, namely, to produce profiles of ulil albab graduates. \\
\hline & Abstrak: Pesantrenisasi merupakan program yang diinisiasi oleh Universitas \\
\hline & Islam Indonesia dalam rangka peningkatan pembelajaran Pendidikan Agama \\
\hline & Islam di perguruan tinggi. Penelitian ini sendiri menggunakan pendekatan \\
\hline & kualitatif dan kuantitatif (mix method). Pendekatan kualitatif dilakukan \\
\hline & $\begin{array}{l}\text { dengan mentelaah sumber pustaka, dokumentasi, observasi kegiatan } \\
\text { pesantrenisasi dan wawancara dengan mahasiswa, musyrif/musyrifah dan }\end{array}$ \\
\hline & dosen Pendidikan Agama Islam. Pendekatan kuantitatif dilakukan dengan \\
\hline & menyebarkan kuesioner dengan teknik random sampling yakni sebesar 60 \\
\hline & responden untuk diolah dengan pendekatan regresi linier melalui perangkat \\
\hline & SPSS 25. Hasil penelitian menunjukkan bahwa terdapat pengaruh program \\
\hline & pesantrenisasi terhadap motivasi hidup Islami mahasiswa yakni 0,461 . \\
\hline & Sedangkan besaran nilai kolerasinya adalah 0,679 . Nilai signifikansi sebesar \\
\hline & 0,000 yakni $<0,05$ maka menunjukkan ada pengaruh pesantrenisasi $(\mathrm{X})$ \\
\hline & si hid \\
\hline
\end{tabular}

\section{Alamat Korespondensi:}

Syahdara Anisa Makruf, Fakultas Bisnis dan Ekonomika Universitas Islam Indonesia

Kaliurang St No.Km. 14,5, Krawitan, Umbulmartani, Ngemplak, Sleman, Yogyakarta, Indonesia 55584 E-mail: 133100508@uii.ac.id

\section{PENDAHULUAN}

Epistimologi Pendidikan Agama Islam diarahkan pada aplikasi dalam mendidik Agama Islam itu sendiri. Inti pembelajaran yang terdapat dalam Pendidikan Agama Islam adalah akidah, ibadah, dan akhlak. Pendidikan Agama Islam merupakan proses internalisasi nilai-nilai secara terencana dan tersistematis dalam mempersiapkan 
peserta didik agar mengenal, memahami, menghayati dan mengimani Islam secara komprehensif (A. Rahman, 2012). Metode pembelajaran Pendidikan Agama Islam dilaksanakan secara bervariasi hal ini dilakukan untuk menghindari dari kejenuhan dalam proses pembelajaran. Dalam pelaksanaannya bisa dilakukan lewat penyampaian langsung atau ceramah, setelah itu tanya-jawab dan diskusi mendalam dari topik yang dibicarakan. Selain itu juga bisa lewat pemberian tugas sesuai dengan tema yang ada, melakukan pengamatan terhadap apa yang telah ditugas dan juga mencari solusi (problem solving) dalam meningkatkan cara berfikir kritis dalam menyelesaikan permasalahan agama dalam kehidupan. Dengan menggunakan metode tersebut, maka mahasiswa akan mendapatkan maanfaat yakni dapat mengembangkan ilmu pengetahuan, menambah pengalaman, meningkatkan keterampilan, membiasakan berpikir kritis serta menciptakan suasana yang kondusif dan komunikatif sehingga mahasiswa termotivasi dalam proses tersebut (Ahyat, 2017).

Dalam mencapai tujuan pendidikan, ditentukan oleh salah satu komponen penting yakni kurikulum. Kurikulum merupakan acuan dalam melaksanakan proses pembelajaran di semua jenjang pendidikan. Keberhasilan pendidikan dalam suatu bangsa ditentukan oleh kurikulum yang bersifat dinamis, hal ini disesuaikan dengan perkembangan yang terjadi. Kurikulum Pendidikan Agama Islam memiliki posisi yang strategis dalam membentuk kepribadian manusia. Akan tetapi, tidak semua pendidik mampu memahami hakikat kurikulum. Hanya dengan memahami kurikulum yang ada para pendidikan akan lebih mudah dalam menjalankan pembelajaran. Sehingga penyusunan kurikulum harus bersifat dapat diterima oleh akal pikiran (Nurmadiah, 2014). Salah satu sistem pendidikan tertua di Indonesia adalah pesantren. Di era kompetitif saat ini tentu dalam mengelola pesantren dibutuhkan inovasi dan kreativitas, tentu saja dengan spirit revitalisasi nilainilai Islam secara komperhensif dan sistemik. Kehadiran pesantren menjadi jawaban dalam menggairahkan mahasiswa dalam membangun kesadaran beragama sehingga tercipta keharmonisan dan kebermanfaatan terhadap ummat sehingga kehidupan lebih bermartabat (Maárif, 2015).

Pesantren memiliki arti sebagai tempat sementara untuk belajar. Sedangkan santri sendiri dalam kamus bahasa Indonesiai memiliki arti sebagai seseorang yang sedang mengikuti proses belajar agama Islam. Hanya saja dalam perjalanannya istilah pesantren mulai mengalami perluasan makna. Sehingga terlihat kalau pesantren ada yang berjangka panjang dan ada yang berjangka pendek. Namun secara umum santri diharapkan oleh masyarakat akan menjadi pengajar agama baik secara akhlak maupun pembelajaran nyata (Shofiyyah et al., 2019).

Pesantren juga dimaknai sebagai tempat pembelajaran ilmu agama secara mendalam. Ilmu tersebut diharapkan dapat dipraktekkan dalam kehidupan sehari hari. Pondok pesantren mengedepankan nilai-nilai keislaman yakni proses penyadaran bahwa hidup adalah untuk senantiasa memperkuat keimanan kepada Allah SWT (aspek aqidah), mendekatkan diri pada RabbNya (aspek ibadah), dan memperbaiki kepribadian (aspek akhlak). Pondok Pesantren memiliki pengaruh yang besar dalam sistem pendidikan di Indonesia. Sistem ini sudah dipakai di pelosok-pelosok negeri ini. Kontribusi yang diberikan juga terlihat menggembirakan. Lulusan pesantren dapat diterima dalam berbagai bidang kehidupan. Berbagai lembaga pemerintah menerima lulusan pesantren dengan terbuka. Termasuk para pemimpin di negeri ini sebagian juga merupakan lulusan pesantren (Mumtahanah, 2015)

Pesantren sebagai tempat untuk membentuk kepribadian yang berkarakter. Maka dari itu pesantren dinilai sebagai tempat yang efektif dalam proses memperbaiki akhlak dengan arahan dan lingkungan yang mendukung. Maka dari itu pesantren tetap dipertahankan dan terus diperbaiki dikarenakan pesantren merupakan salah satu tempat untuk ikhtiar menyelesaikan permasalahan Pendidikan Agama Islam ditengah era globalisasi bahkan era disrupsi saat ini sehingga keberadaan pesantren dikenal dengan pembangunan karakter bagi bangsa. Oleh sebab itu pesantren diharapkan akan menjadi pelangsung dan penyempurna kepemimpinan yang bertaqwa, memiliki kecakapan, berbudi luhur untuk kemaslahatan bangsa Indonesia (Mas' udi, 2014). Implementasi pesantrenisasi di Perguruan Tinggi Umum merupakan langkah efektif untuk menginternalisasi nilai-nilai keislaman dan berupaya untuk mempertemukan agama dan sains. Hal ini merupakan solusi strategis dalam mewujudkan pendidikan yang holistik. Mahasiswa akan mendapatkan keutuhan ilmu sehingga mampu membuka wacana, ruang diskusi dan meningkatkan pemikiran yang kritis sehingga melahirkan mahasiswa yang memiliki kepribadian yang ulil albab (Munif \& Baharun, 2018).

Di era disrupsi, pesantren memiliki tantangan yang besar bagi dunia pendidikan Islam. Dalam hal ini menjadi perhatian bersama agar mampu menyikapi era ini dengan langkah yang bijak. Sikap bijak dalam menghadapi tantangan zaman ini adalah dengan mengintegrasikan sains dan agama dalam sebuah kurikulum yang menjadi kebutuhan santri yang siap bersaing secara global dan yang terpenting mampu hadir di tengahtengah masyarakat sebagai pemimpin yang turut serta memecahkan masalah keummatan. Dalam pelaksanaan 
pesantrenisasi tentu bisa dikembangkan dengan kurikulum berbasis soft skill, dimana santri memiliki keterampilan tertentu untuk memecahkan masalah kehidupan (Fauzan, 2017). Pesantren modern merupakan pesantren yang mengalami perubahan sosial dan senantiasa memajukan ilmu pengetahuan dan juga teknologi (Arifin, 2012).

Secara etimologi motivasi berasal dari bahasa latin yaitu movere yang bermakna menggerakkan atau dalam bahasa Inggris disebut sebagai motivation yang berarti pemberian motif atau menimbulkan motif atau dorongan (Stevani, 2016), Sedangkan (Sardiman, 2014) menyatakan motivasi memiliki asal kata "motif" yang bisa dimaknai sebagai daya gerak manusia untuk bersifat aktif. Ini berarti manusia dalam kondisi tertentu bisa menjadi aktif dan bisa menjadi pasif. Sedangkan menurut (Djaali, 2013) motivasi adalah kondisi fisiologis dan psikologis yang ada pada diri peserta didik untuk melakukan atau melaksanakan aktivitas tertentu dengan tujuan tertentu. Sedangkan menjelaskan motivasi merupakan motif untuk berhasil dalam menjalankan tugas atau pekerjaan untuk dapat berprestasi (Uno, 2007). Sedangkan (S. A. Rahman \& Wahab, 2004) memberikan tiga komponen penting dalam pengertian motivasi:

a) Menggerakkan, ini terkait dengan kekuatan individu dalam menimbulkan atau membuat orang untuk bertindak dengan kriteria tertentu.

b) Mengarahkan, motivasi memberikan arahan pada individu tertentu untuk dapat melakukan perilaku tertentu. Dari sini terjadi adanya orientasi dan tujuan tertentu, tingkah laku seseorang terhadap sesuatu yang diharapkan.

c) Mendorong, dengan artian lingkungan yang telah diciptakan dapat memberikan dorongan pada individu tertentu untuk berbuat atau melakukan sesuatu.

Dari penjelasan ini terlihat motivasi sebagai sebuah kata yang dipergunakan untuk mendorong seseorang dalam melakukan tindakan sesuai dengan apa yang dikehendaki. Dalam hal ini motivasi menjadi kekuatan pada diri setiap orang untuk menjadi lebih berarti atau mempunyai dasar dalam melakukan tindakan yang lebih baik. Secara tersirat Trinurmi mengisyarakatkan Jika hidup Islami merupakan sebuah kondisi kejiwaan manusia yang dibawa oleh lingkungannya. Dalam hal ini didasarkan pada Al-Quran dan Sunnah yang merupakan dua sumber rujukan utama umat Islam. Sebab terdapat dua kehidupan yang sedang dan akan dilalui oleh manusia yaitu kehidupan dunia dan akhirat. Prespektif hidup Islami mengisyaratkan manusia untuk dapat menjalankan keduanya secara bersamaan (Trinurmi, 2015). Dalam Surah Al- Qashash ayat 77: "Dan carilah (pahala) negeri akhirat dengan apa yang telah dianugerahkan Allah kepadamu, tetapi janganlah kamu lupakan bagianmu di dunia dan berbuat baiklah (kepada orang lain) sebagaimana allah telah berbuat baik kepadamu, dan janganlah kamu berbuat kerusakan di bumi. Sungguh, Allah tidak menyukai orang yang berbuat kerusakan.”

Sedangkan di Muhammadiyah mengatakan jika hidup Islami adalah hidup yang ditujukan agar dapat menciptakan umat Islam yang sesuai dengan tuntunan dan tuntutan Al-Quran. Penekanannya terdapat upaya agar selalu menjadi individu yang selalu menjadikan agama Islam sebagai pedoman hidup. Secara tersurat juga mengisyaratkan jika secara duniawi masyarakat Islam harus berlandaskan Al-Quran dan Sunnah (Shaleh, 2015). Sedangkan Suryadi menjelaskan jika hidup Islami adalah hidup yang didasarkan pada ketentuan Al-Quran dan Hadits. Sedangkan Al-Quran sendiri memberikan penekanan jika hidup Islami adalah hidup yang ditujukan untuk mencari, menemukan dan mendapatkan ridho Allah SWT. Pengertian kata ridho disini tidak hanya dalam arti rela dan ikhlas, melainkan juga sikap manusia untuk tidak membenci apa yang telah menjadi ketetapannya, dalam hal ini takdir yang telah diberikan. Pandangan ini sebenarnya lebih mengarahkan makna Islami dengan pengertian tasawuf (Suryadi, 2013).

Dari ketiga pengertian yang sudah dijelaskan jelas bahwa hidup Islami merupakan kehidupan yang disandarkan pada Al-Quran dan Hadits. Dengan menjadikannya sebagai pedoman dalam kehidupan sehari-hari. Namun dalam tingkat yang lebih tinggi hidup Islami merupakan segala sesuatu yang dilaksanakan oleh manusia dalam rangka mencari dan mendapatkan ridho Allah SWT. Sedangkan pengertian motivasi hidup Islami dapat dijabarkan dengan menggabungkan penjelasan yang sudah tertera yaitu segala dorongan, arahan dan gerakan yang ditujukan untuk menjalankan kehidupan yang berlandaskan pada Al-Quran dan Hadits. Motivasi ini bisa dilakukan lewat program yang sudah direncanakan atau secara personal seseorang mendorong dirinya sendiri lewat membaca atau mengikuti kajian. Menurut Ilyas motivasi hidup Islami sudah terdapat dalam Al-Quran sendiri dengan memberikan imbalan bagi mereka yang hidup Islami dan ganjaran jika mereka hidup tidak Islami. Ini didasarkan pada hakikat ibadah yang sudah terdapat di dalam Al-Quran (Ilyas, 2013). 
Upaya ini ditujukan dalam rangkan menjalani kehidupan dunia dengan tetap menjadikan akhirat sebagai tujuan utama. Pendekatan ini juga dapat mendorong seseorang untuk menjadi lebih dekat pada Allah SWT. Sebab manusia seringkali didorong oleh faktor lingkungan yang belum tentu sesuai dengan ajaran dan anjuran dalam Islam. Motivai hidup Islami juga berlandaskan pada prinsip mendasar dalam menjalankan ibadah dalam Islam. Artinya seseorang yang memiliki motivasi hidup Islami berarti memiliki motivasi dalam menjalankan perintah Allah dan meninggalkan larangan Allah. Dalam hal ini disebut sebagai ibadah, sedangkan ibadah sendiri terdapat dua kategori ibadah khusus dan ibadah umum. Ibadah khusus merupakan ibadah yang sudah ada ketentuannya dengan jelas dan ketat dalam Al-Quran dan Hadits. Sedangkan ibadah umum merupakan ibadah yang ketentuannya tidak diatur secara rigit.

\section{MIETODE}

\section{Jenis Penelitian}

Jenis penelitian ini berdasarkan pada judul dan permasalahan yang telah dipaparkan sebelumnya, penulis menggunakan jenis penelitian kualitatif dan kuantitatif atau disebut juga sebagai mix method. Penelitian kualitatif ini akan mendeskripsikan secara holistik tentang revitalisasi nilai-nilai Pendidikan Agama Islam melalui program pesantrenisasi. Sedangkan jenis kuantitatif dimana penulis menganalisis pengaruh program pesantrenisasi terhadap kehidupan Islami mahasiswa. Metode penelitian kuantitatif diartikan sebagai metode penelitian yang berlandaskan pada filsafat positivisme, digunakan untuk meneliti pada populasi atau sampel tertentu, pengumpulan data menggunakan instrumen penelitian, analisis data bersifat kuantitatif/statistik, dengan tujuan untuk mengaju hipotesis yang telah ditetapkan (Sugiyono, 2018).

\section{Populasi dan Sampel}

Populasi merupakan keseluruhan dari obyek penelitian yang memiliki kriteria tertentu dalam sebuah penelitian. Penelitian ini menjadikan Mahasiswa Universitas Islam Indonesia yang telah melaksanakan program pesantrenisasi sebagai sampel. Proses pengambilan populasi penelitian difokuskan pada mahasiswa Program Diploma Tiga Fakultas Bisnis Ekonomika Universitas Islam Indonesia. Sedangkan sampel merupakan sebagian anggota dari populasi yang diambil oleh peneliti melalui teknik simple random sampling.

\section{Variabel}

Variabel penelitian adalah atribut dari seseorang atau objek yang mempunyai "variasi" antara satu orang dengan yang lain atau satu objek dengan objek yang lain. Dalam penelitian ini terdiri dari dua variabel yaitu variabel bebas $(\mathrm{X})$ dan variabel terikat $(\mathrm{Y})$ (Sugiyono, 2018). Variabel bebas (X) adalah variabel yang mempengaruhi terhadap suatu gejala. Variabel bebas dalam penelitian ini adalah program pesantrenisasi. Sedangkan variabel terikat $(\mathrm{Y})$ adalah variabel yang dipengaruhi oleh suatu gejala. Variabel terikat dalam penelitian ini adalah kualitas hidup Islami mahasiswa dengan indikator aspek aqidah, ibadah dan akhlak.

\section{Metode Pengumpulan Data}

\section{Observasi}

Peneliti melakukan pengamatan, dimana proses pengamatan ini merupakan hal-hal yang terjadi di lapangan kemudian dilakukan pencatatan yang bersifat logis dan sistematis. Kunci dari kesuksesan melakukan pengamatan berasal dari peneliti sendiri, hal ini dikarenakan peneliti melihat dan merasakan secara langsung terhadap masalah di lapangan. Tujuan pengamatan ini akan melahirkan hipotesis pada penelitian kualitatif dimana terdapat deskripsi dan penyajian data awal yang dapat diperluas atau digeneralisasikan (Hasanah, 2017). Terdapat dua jenis observasi dalam penelitian ini. Pertama observasi partisipasi yakni peneliti mengamati secara mandiri dan terlibat bersama dengan informan, kedua observasi tidak terstruktur yakni peneliti mengamati mengembangkan permasalahan yang ada dan terakhir pengamatan kelompok, yakni pengamatan permasalahan yang dijalankan oleh tim pada obyek penelitian.

\section{Wawancara}

Wawancara merupakan proses menggali informasi dengan cara membangun komunikasi dengan informan atau subyek penelitian baik secara kultural maupun informal. Wawancara mendalam dalam penelitian kualitatif dilakukan secara spontanitas. Hubungan yang dibangun antara peneliti dengan informan sepertia halnya suasana 
biasa. Tujuan wawancara mendalam ini adalah untuk menyajikan konteks tentang kegiatan dan keterlibatan informan (Yusuf, 2014). Dalam hal ini, informan yang dipilih oleh peneliti adalah DPPAI, dosen mata kuliah agama Islam, Musyrifah dan mahasiswa diploma 3 FBE UII.

\section{Dokumentasi}

Proses pengumpulan data selain meggunakan observasi dan wawancara, informasi dapat diperoleh dari dokumen yakni beberapa hasil rapat, catatan harian, foto dokumentasi kegiatan, jurnal, arsip kurikulum yang digunakan dan sebagainya. Dalam hal ini dibutuhkan respect teoritik dalam memahami dokumen sebagai proses menelusuri data historis dalam setiap kejadian situasi sosial yang bermanfaat dalam proses penelitian ini (Yusuf, 2014). Peneliti mempelajari dokumen kurikulum ulil albab Universitas Islam Indonesia dalam rangka mencari latar belakang UII mewajibkan mahasiswa mengikuti kegiatan pesantrenisasi, dan dalam pelaksanaan pesantrenisasi peneliti menggunakan buku panduan Direktorat Pendidikan dan Pembinaan Agama Islam, selain itu ada beberapa dokumen dari hasil rapat tim hingga evalusi dalam kegiatan pesantrenisasi.

\section{Studi Pustaka}

Selain melalui teknik wawancara, penelitian ini juga mengumpulkan data lewat tela'ah pustaka atau studi pustka. Studi ini sendiri dilakukan dengan menyeleksi bahan yang sudah ada dalam bentuk jurnal, buku, modul atau tulisan yang kredibel lainnya untuk dijadikan sebagai rujukan. Khususnya dalam membuat kerangka teoritis yang merupakan alat analisis dalam melakukan penelitian ini.

\section{Kuesioner}

Metode pengumpulan data yang kedua adalah dengan melakukan penyebaran angket kepada mahasiswa yang telah mengikuti program pesantrenisasi sebagai responden. Mahasiswa ini bersatus mahasiswa aktif program Diploma Tiga Fakultas Ekonomi dan Bisnis Universitas Islam Indonesia untuk kemudian dianalisis melalui regresi linier.

\section{Uji Validitas dan Reliabilitas Kuesioner Penelitian}

Proses pengambilan data melalui kuesioner membutuhkan ketelitian yang mendalam. Hal ini disebabkan bahwa kedudukan instrument dalam penelitian ini sangat penting. Instrumen yang valid maupun yang reliabel mampu menghasilkan kesimpulan yang tepat. Ketepatan ini ditentukan oleh validitas isi, arahan dan karakteristik. Semakin nilai koefisien validitas mendekati $+1,00$ maka instrumen diindikasi semakin valid. Sedangkan Reliabilitas mendiskusikan tentang sejauh mana suatu pengukuran dapat dipercaya karena kekonsistennya. dikatakan reliabel jika koefisien reliabilitas Alfa Cronbach di antara 0,70- 0,90 (Yusup, 2018).

\section{HASIL}

Peneliti mengambil sampel sebanyak 60 responden dari tiga program studi di Diploma Tiga Fakultas Bisnis Ekonomika Universitas Islam Indonesia. Pengambilan sampel ini menggunakan teknik simple random sampling. Penyebaran kuesioner dilakukan melalui google form untuk selanjutkan dimasukkan ke dalam excel dan diolah dengan SPSS 25. Untuk mengetahui apakah ada pengaruh tidaknya program pesantrenisasi terhadap motivasi hidup Islami mahasiswa, data diolah dengan regresi linier sehingga menghasilkan output dapat dilihat pada Tabel 1 .

Tabel 1. Variables Entered/Removeda

\begin{tabular}{cccc}
\hline Model & Variables Entered & Variables Removed & Method \\
\hline 1 & Pesantrenisasib & Enter \\
& a. Dependent Variable: Motivasi Hidup Islami & \\
& b. All requested variables entered. & \\
\hline
\end{tabular}

Tabel 1 menjelaskan jika independent variabel dalam penelitian ini adalah pesantrenisasi sedangkan dependent variabelnya motivasi hidup Islami dengan menggunakan metode enter. Pada Tabel 2 menunjukkan bahwa besaran pengaruh pesantrenisasi terhadap motivasi hidup Islami mahasiswa yakni terdapat dalam table $\mathrm{R}$ square yakni 0,461. Sedangkan besaran nilai kolerasi (hubungan R) pada tabel $\mathrm{R}$ adalah 0,679. Tabel 3 menunjukkan nilai $\mathrm{F}$ sebesar 53,893 sedangkan nilai signifikansi sebesar 0,000 yakni $<0,05$ sehingga 
menunjukkan ada pengaruh pesantrenisasi (X) terhadap Motivasi hidup Islami mahasiswa (Y). Tabel 4 atau output keempat yakni tabel coefficients dengan nilai constant (a) yakni 2,517 sedangkan nilai pesantrenisasi (koefisien regresi b) yakni 0,639. Sehingga persamaan regresinya ditulis sebagai berikut:

$$
\begin{gathered}
\mathrm{Y}=\mathrm{a}+\mathrm{bX} \\
\mathrm{Y}=2,517+0,639 \mathrm{X}
\end{gathered}
$$

Tabel 2. Model Summary

\begin{tabular}{ccccc}
\hline Model & R & R Square & Adjusted R Square & Std. Error of the Estimate \\
\hline 1 & $.679^{\mathrm{a}}$ & .461 & .452 & 1.840 \\
& & a. Predictors: (Constant), pesantrenisasi & \\
\hline
\end{tabular}

Tabel 3. Anova a

\begin{tabular}{ccccccc}
\hline & Model & Sum of Squares & Df & Mean Square & F & Sig. \\
\hline 1 & Regression & 182.475 & 1 & 182.475 & 53.893 & $.000^{\mathrm{b}}$ \\
& Residual & 213.310 & 63 & 3.386 & & \\
& Total & 395.785 & 64 & & & \\
\multicolumn{5}{r}{} & \multicolumn{3}{c}{$\begin{array}{l}\text { a. Dependent Variable: Motivasi Hidup Islami } \\
\text { b. Predictors: (Constant), pesantrenisasi }\end{array}$} \\
\hline
\end{tabular}

Tabel 4. Coefficientsa

\begin{tabular}{lcccccc}
\hline \multirow{2}{*}{ Model } & \multicolumn{2}{c}{ Unstandardized Coefficients } & Standardized Coefficients & T & Sig. \\
\cline { 3 - 5 } & & $\mathrm{B}$ & Std. Error & Beta & & \\
\hline 1 & (Constant) & 2.517 & 2.011 & & 1.251 & .215 \\
& Pesantrenisasi & .639 & .087 & .679 & 7.341 & .000 \\
& & \multicolumn{2}{c}{ a. Dependent Variable: Hidup Islami } & & \\
\hline
\end{tabular}

Persamaan di atas dapat diterjemahkan bahwa nilai constanta a Motivasi hidup Islami yakni 2,517. Koefisien regresi X sebesar 0,639 menyatakan bahwa setiap ada penambah $1 \%$ nilai pesantrenisasi dapat diterjemahkan bahwa ada arah pengaruh $\mathrm{X}$ terhadap $\mathrm{Y}$ sehingga pengaruh pesantrenisasi terhadap motivasi hidup Islami mahasiswa adalah positif. Pengambilan keputusan regresi linier sederhana di atas adalah jika berdasarkan nilai signifikansi: dari tabel coefficients di atas dengan nilai signifikansi sebesar $0.000<0,05$ sehingga dapat disimpulkan bahwa ada pengaruh postif pesantrenisasi (X) terhadap motivasi hidup Islami mahasiswa (Y).

Validitas dan reliabilitas dalam sebuah instrument penelitian merupakan syarat pertama dalam proses mengumpulkan data penelitian. Instrument disebut dengan valid jika bias diukur apa yang akan diukur sedangkan data dikatan reliabel jika data stabil dan konsisten dalam satu waktu. Validitas variabel pesantrenisasi terdapat lima soal dengan 60 responden. Data dikatakan valid jika nilai person correlation $>0,3$. Data pada Tabel 5 menunjukkan bahwa setiap butir soal dalam variabel pesantrenisasi (X) adalah valid.

Tabel 5. variabel pesantrenisasi

\begin{tabular}{lcccccc}
\hline & & X1 & X2 & X3 & X4 & X5 \\
\hline X1 & Pearson Correlation & 1 & $.637^{* *}$ & $.374^{* *}$ & $.443^{* *}$ & $.463^{* *}$ \\
& Sig. (2-tailed) & & .000 & .003 & .000 & .000 \\
& N & 60 & 60 & 60 & 60 & 60 \\
X2 & Pearson Correlation & $.637^{* *}$ & 1 & .208 & $.384^{* *}$ & $.513^{* *}$ \\
& Sig. (2-tailed) & .000 & & .111 & .002 & .000 \\
& $\mathrm{~N}$ & 60 & 60 & 60 & 60 & 60 \\
X3 & Pearson Correlation & $.374^{* *}$ & .208 & 1 & $.483^{* *}$ & $.560^{* *}$ \\
& Sig. (2-tailed) & .003 & .111 & & .000 & .000 \\
& $N$ & 60 & 60 & 60 & 60 & 60 \\
X4 & Pearson Correlation & $.443^{* *}$ & $.384^{* *}$ & $.483^{* *}$ & 1 & $.762^{* *}$ \\
& Sig. (2-tailed) & .000 & .002 & .000 & & .000 \\
& $\mathrm{~N}$ & 60 & 60 & 60 & 60 & 60 \\
X5 & Pearson Correlation & $.463^{* *}$ & $.513^{* *}$ & $.560^{* *}$ & $.762^{* *}$ & 1 \\
& Sig. (2-tailed) & .000 & .000 & .000 & .000 & \\
\hline & & & & & & \\
\hline
\end{tabular}




\begin{tabular}{rccccc}
\hline & X1 & X2 & X3 & X4 & X5 \\
\hline $\mathrm{N}$ & 60 & 60 & 60 & 60 & 60 \\
$* *$ Correlation is significant at the 0.01 level & (2-tailed). & \\
\hline
\end{tabular}

Sedangkan Cronbach's Alpha di bawah ini menunjukkan $>0,6$ yakni 0,823 sehingga data ini berniali Reliabel disajikan pada Tabel 6 dan 7.

Tabel 6. Case Processing Summary

\begin{tabular}{|c|c|c|c|}
\hline \multicolumn{4}{|c|}{$\mathbf{N}$} \\
\hline \multirow[t]{3}{*}{ Cases } & Valid & 60 & \\
\hline & Excluded ${ }^{\mathrm{a}}$ & 0 & \\
\hline & Total & 60 & \\
\hline \multicolumn{4}{|c|}{$\begin{array}{c}\text { a. Listwise deletion based on all variab } \\
\text { the procedure. }\end{array}$} \\
\hline \multicolumn{4}{|c|}{ Tabel 7. Reliability Statistics } \\
\hline & $\begin{array}{l}\text { Cronbach's } \\
\text { Alpha }\end{array}$ & $\mathrm{N}$ of & tems \\
\hline & .823 & & \\
\hline
\end{tabular}

Output di atas menunjukkan bahwa data bernilai Valid dan Reliabel. Sedangkan pada variabel butir soal Motivasi Hidup Islam (Y) menghasilkan output dapat dilihat pada Tabel 8:

Tabel 8. Correlations

\begin{tabular}{|c|c|c|c|c|c|c|}
\hline & & Y1 & Y2 & Y3 & Y4 & Y5 \\
\hline \multirow[t]{3}{*}{$\mathrm{Y} 1$} & Pearson Correlation & 1 & $.693^{* *}$ & $.801^{* *}$ & $.708^{* *}$ & $.469^{* *}$ \\
\hline & Sig. (2-tailed) & & .000 & .000 & .000 & .000 \\
\hline & $\mathrm{N}$ & 60 & 60 & 60 & 60 & 60 \\
\hline \multirow[t]{3}{*}{$\mathrm{Y} 2$} & Pearson Correlation & $.693^{* *}$ & 1 & $.801^{* *}$ & $.716^{* *}$ & $.548^{* *}$ \\
\hline & Sig. (2-tailed) & .000 & & .000 & .000 & .000 \\
\hline & $\mathrm{N}$ & 60 & 60 & 60 & 60 & 60 \\
\hline \multirow[t]{3}{*}{ Y3 } & Pearson Correlation & $.801^{* *}$ & $.801^{* *}$ & 1 & $.711^{* *}$ & $.537^{* *}$ \\
\hline & Sig. (2-tailed) & .000 & .000 & & .000 & .000 \\
\hline & $\mathrm{N}$ & 60 & 60 & 60 & 60 & 60 \\
\hline \multirow[t]{3}{*}{$\mathrm{Y} 4$} & Pearson Correlation & $.708^{* *}$ & $.716^{* *}$ & $.711^{* *}$ & 1 & $.368^{* *}$ \\
\hline & Sig. (2-tailed) & .000 & .000 & .000 & & .004 \\
\hline & $\mathrm{N}$ & 60 & 60 & 60 & 60 & 60 \\
\hline \multirow[t]{4}{*}{ Y5 } & Pearson Correlation & $.469^{* *}$ & $.548^{* *}$ & $.537^{* *}$ & $.368^{* *}$ & 1 \\
\hline & Sig. (2-tailed) & .000 & .000 & .000 & .004 & \\
\hline & $\mathrm{N}$ & 60 & 60 & 60 & 60 & 60 \\
\hline & $* *$. Correlation is & icar & the & leve & tail & \\
\hline
\end{tabular}

Hasil data pearson correlations dalam setiap butir soal Motivasi Hidup Islam dalam hal ini sebagai variabel (Y) menujukkan angka >0,3 sehingga data setiap butir soal menghasilkan data Valid. Sedangkan ujia Realiabilitas datanya dapat dilihat pada Tabel 9 dan 10 .

Tabel 9. Case Processing Summary

\begin{tabular}{lccc}
\hline & & $\mathbf{N}$ & $\%$ \\
\hline Cases & Valid & 60 & 100.0 \\
& Excluded $^{\mathrm{a}}$ & 0 & .0 \\
Total & 60 & 100.0 \\
a. Listwise deletion based on all variables in \\
the procedure.
\end{tabular}


Tabel 10. Reliability Statistics

$\begin{array}{r}\hline \text { Cronbach's Alpha N of Items } \\ \hline .893 \quad 5 \\ \hline\end{array}$

Kesimpulan di atas menunjukkan bahwa besaran Cronbach's Alpha > 0,6 yakni 0,893. Sehingga butir soal dalam variabel Motivasi Hidup Islami adalah Variabel.

\section{PEMBAHASAN}

Dari data yang dipaparkan sebelumnya ditemukan jika program pesantrenisasi memiliki pengaruh langsung terhadap motivasi hidup Islami. Program ini menjadi cara atau jalan untuk mahasiswa dapat memperbaiki diri mahasiswa terutama dari segi kualitas nilai-nilai agama Islam. Sebagaimana yang telah disebutkan oleh (Napsiah, 2012) bahwa penanaman nilai-nilai dapat dilakukan dengan rekayasa program yang tepat. Rekayasa program ini dilakukan dalam berbagai bentuk dan upaya agar mahasiswa kembali pada nilai dasar kehidupan umat Islam. Seperti pada program pesantrenisasi ini dilaksanakan dengan meningkatkan kapasistas ilmu pengetahuan agama serta implementasinya dalam kehidupan sehari-hari.

Dari segi pembelajaran, materi yang disampaikan disesuaikan dengan kebutuhan mahasiswa. Kebutuhan tersebut terdapat dalam nilai-nilai aqidah, ibadah dan akhlak. Ketiga hal ini merupakan inti dari ajaran Islam yang menjadi pondasi kehidupan. Nilai aqidah berhubungan dengan keimanan mahasiwa. Sedangkan nilai ibadah merupakan bentuk kewajiban manusia dalam membuktikan keyakinannya terhadap Allah SWT. Sedangkan akhlak merupakan representasi hubungan manusia dengan manusia lainnya atau dengan lingkungan. Supaya terasa dekat dengan mahasiswa maka studi kasus yang diberikan juga disesuaikan dengan dunia mereka. Seperti nilai tauhid dengan membicarakan posisi akal dan wahyu. Akal dan wahyu merupakan representasi terhadap hubungan antara agama dengan ilmu pengetahuan. Keduanya dalam beberapa literasi dianggap bertentangan, terutama dalam pandangan kaum sekuler. Sedangkan bagi umat Islam sebenarnya menganggap jika keduanya memiliki hubungan yang saling melengkapi.

Sedangkan dari segi fasilitas yang sudah diberikan, program pesantrenisasi sudah sesuai dengan harapan mahasiswa. Ini dilaksankan dengan berupaya semaksimal mungkin agar mahasiswa nyaman selama melakukan kegiatan tersebut. Dilihat dari segi pemenuhan kebutuhan akomodasi dan tindakan pencegahan terhadap adanya hal-hal yang berada diluar kendali. Disamping itu juga setiap mahasiswa diberikan kamar dan ruang kamar mandi yang ideal. Termasuk ruang pembelajaran yang tidak terlalu sempit. Sehingga membuat mahasiwa merasa nyama selama proses pembelajaran. Disamping itu juga terdapat pendamping (musyrif/musyrifah) yang berfungsi sebagai mediator dalam hubungan antara peserta dengan panitia. Peran pendamping juga dalam rangka memberikan dorongan dan motivasi dalam setiap kegiatan yang dilaksanakan.

Khusus untuk pemateri, diambil dari dosen-dosen yang memiliki kapasitas dalam bidangnya masing-masing. Mereka merupakan tenaga pengajar dari berbagai fakultas dan jurusan yang ada di Universaitas Islam Indonesia. Dengan latar belakang keilmuan yang sudah mereka tekuni dapat memberikan pengaruh langsung terhadap mahasiswa. Pemateri juga diharuskan untuk bersikap profesional. Dengan datang tepat waktu, memberikan makalah atau ppt sebelum dilakukannya program. Disamping itu juga mereka harus membuat soal untuk diujikan setelah program berakhir. Ini ditujukan supaya sikap profesional ini memberikan dampak terhadap pandangan mahasiswa tentang arti hidup disiplin. Sebab dalam Islam disiplin itu memiliki padanan kata yang serupa dengan istiqomah.

Hanya saja dari segi metode pola pembelajaran masih klasik. Dilakukan dengan proses satu arah, dimana pemateri menjadi subjek sedangkan mahasiswa menjadi objek. Kondisi ni berdampak pada penilaian mahasiswa dari sebaran kuesioner yang diberikan terlihat penilaian mahasiswa berada pada angka rata-rata. Hal ini terjadi karena mahasiswa vokasi sebenarnya diharapkan untuk menjadi praktisi. Pola pikir praktisi sebenarnya lebih mengedepankan praktek dari pada teori yang ada. Oleh sebab itu pemateri sudah seharusnya memberikan metode pembelajaran yang lebih komunikatif dan proaktif terhadap mahasiswa.

\section{SIMPULAN}

Program pesantrenisasi merupakan program yang diselenggarakan oleh Universitas Islam Indonesia. Program ini mempunyai tujuan untuk meningkatan nilai dasar Islam bagi mahasiswa. Nilai ini teraktualisasi dalam nilai aqidah, ibadah dan akhlak. Dari penelitian ini dapat disimpulkan bahwa revitalisasi program 
pesantrenisasi dibutuhkan dalam rangka memperkuat jati diri mahasiswa sebagai insan ulil albab. Revitalisasi ini dapat dilaksanakan lewat penyempurnaan materi, peningkatan metode, peningkatan fasilitas sampai pemateri itu sendiri. Dari penelitian ini juga ditemukan pengaruh yang kuat antara upaya revitalisasi pesantrenisasi terhadap motivasi hidup Islami. Motivasi hidup Islami ini dimaksudkan dengan tujuan mendekatkan diri pada Allah SWT dengan melakukan perintah-peritahnya yang sudah tertulis dalam Al-Quran dan Sunnah. Kesimpulan ini juga menunjukkan jika program pesantrenisasi merupakan salah satu metode yang tepat bagi mahasiswa. Walaupun dalam beberapa hal masih harus ada perbaikan. Namun setidaknya program ini masih memberikan dampak yang besar bagi perubahan dalam diri mahasiswa yang mampu mengintegrasikan ilmu agama dengan program studi umum yang dipilih.

\section{DAFTAR RUJUKAN}

Ahyat, N. (2017). Metode pembelajaran pendidikan agama Islam. Edusiana: Jurnal Manajemen Dan Pendidikan Islam, $4(1), 24-31$.

Arifin, Z. (2012). Perkembangan pesantren di Indonesia. Jurnal Pendidikan Agama Islam, 9(1), 40-53.

Djaali, H. (2013). Psikologi pendidikan (Cet. 7). In Jakarta: PT. Bumi Aksara.

Fauzan, F. (2017). Urgensi kurikulum integrasi di pondok pesantren dalam membentuk manusia berkualitas. Fikrotuna, $6(2)$.

Hasanah, H. (2017). Teknik-teknik observasi (sebuah alternatif metode pengumpulan data kualitatif ilmu-ilmu sosial). AtTaqaddum, 8(1), 21-46.

Ilyas, S. (2013). Metode Al-Quran membangun motivasi beribadah: Kajian Tafsir Maudhu’i. IAIN Ar-Raniry.

Maárif, S. (2015). The revitalization of pesantren: Philosophical thinking to direction universalization of Islamic values. Global Research Journal Of Education, 3(5), 314-320.

Mas' udi, A. (2014). Peran pesantren dalam pembentukan karakter bangsa. Jurnal Paradigma, 1(1).

Mumtahanah, N. (2015). Pengembangan sistem pendidikan Pesantren dalam meningkatkan profesionalisme Santri. Al Hikmah: Jurnal Studi Keislaman, 5(1), 54-70.

Munif, M., \& Baharun, H. (2018). Perguruan tinggi berbasis pesantren: Menggagas interkoneksi agama dan sains. Jurnal Penelitian, 12(1), 137-146.

Nurmadiah, N. (2014). Kurikulum pendidikan agama Islam. In Al-Afkar: Jurnal Keislaman \& Peradaban (Vol. 2, Issue 2).

Rahman, A. (2012). Pendidikan Agama Islam dan Pendidikan Islam-tinjauan epistemology dan isi-materi. Jurnal Eksis, $8(1), 2053-2059$.

Rahman, S. A., \& Wahab, M. A. (2004). Psikologi suatu pengantar dalam perspektif Islam. In Prenada Media. Jakarta. Prenada Media.

Sardiman, S. (2014). Interaksi dan motivasi belajar mengajar. PT Raja Grafindo Persada.

Shaleh, R. (2015). Pedoman hidup Islami: Universitas Muhammadiyah Yogyakara.

Shofiyyah, N. A., Ali, H., \& Sastraatmadja, N. (2019). Model pondok pesantren di era milenial. Belajea; Jurnal Pendidikan Islam, 4(1), 1-18.

Stevani, S. (2016). Analisis pengaruh motivasi belajar terhadap hasil belajar ekonomi siswa kelas X SMK Negeri 5 Padang. Jurnal of Economic Education, 4(2), 308-314.

Sugiyono, D. (2018). Metode penelitian kuatintatif, kualitatif dan R \& D. In Bandung: Alfabeta (Vol. 15, Issue 2010).

Suryadi, R. A. (2013). Mardhat Allah: Tujuan hidup Qurani. Jurnal Pendidikan Agama Islam-Ta" Lim, 1.

Trinurmi, S. (2015). Hakekat dan tujuan hidup manusia dan hubungannya dengan tujuan pendidikan Islam. Al-Irsyad AlNafs: Jurnal Bimbingan Dan Penyuluhan Islam, 2(1).

Uno, H. B. (2007). Teori motivasi dan pengukuran. Bumi Aksara.

Yusuf, A. M. (2014). Metode penelitian kuantitatif, kualitatif, \& penelitian gabungan. Deeplish.

Yusup, F. (2018). Uji validitas dan reliabilitas penelitian kuantitatif. Tarbiyah, 7(1). 